\title{
EFEKTI OBNAVLJANJA LUŽNJAKA U SREMU NA JEDNOJ TRAJNOJ OGLEDNOJ POVRŠINI - NAKON DVE DECENIJE*
}

\section{Effects of common oak regeneration on a permanent sample plot in Srem - after two decades}

\author{
Martin Bobinac ${ }^{1}$
}

\begin{abstract}
The effects of common oak regeneration were analysed in a permanent sample plot $(\mathrm{P}=0.20 h a)$, established on the site of common oak and narrow-leaved ash forest (Fraxino angustifoliae-Quercetum roboris Jov. et Tom. 1979, subass. aceretosum - on moister semigleys and drier gleys) in the area of southwest Srem (Serbia). The sample plot research during 2 decades included the period of stand establishment, the structure of the regeneration in the eighth year and saplings in $19^{\text {th }}$ year of age. The stand was established by the combined regeneration in the system of regeneration felling, with the preliminary application of herbicides (Glyphosate with $480 \mathrm{~g} \cdot \mathrm{L}^{-1}$ ) to destroy the coppice woody species in the shrub layer. In the $8^{\text {th }}$ year woody species were represented on the sample plot by $89500 \mathrm{pcs} \cdot \mathrm{ha}^{-1}$, and common oak amounted to $42000 \mathrm{pcs} \cdot h \mathrm{a}^{-1}$. In the total new growth structure, common oak accounted for $46.9 \%$, narrow-leaved ash accounted for $0.8 \%$, other tree species - edificators $-14.5 \%$, and shrubby species $-37.7 \%$. The saplings at the age of 19 years consisted of ten tree species, with altogether 12,341 trees per $h a^{-1}$ with diameter above $1 \mathrm{~cm}$, and the percentage of common oak accounted for $68.3 \%\left(8430\right.$ trees $\left.^{\prime} h a^{-1}\right)$. At the ages from 8 to 19 years, common oak mortality was estimated to $80 \%$.
\end{abstract}

Key words: Quercus robur L., regeneration, permanent plots, young growth, sapling.

\section{Izvod}

Efekti obnavljanja lužnjaka analizirani su na jednoj trajnoj oglednoj površini $(\mathrm{P}=0,20$ ha), koja je formirana na staništu šume lužnjaka i poljskog jasena (Fraxino angustifoliae-Quercetum roboris Jov. et Tom. 1979, subass. aceretosum-na vlažnijim

\footnotetext{
* Rad prezentiran na međunarodnoj naučnoj Konferenciji "Šumarska nauka između ekonomije i zahtjeva društva", povodom 60. godišnjice Šumarskog fakulta Univerziteta u Sarajevu, Sarajevo, hotel "Hollywood" 8 - 10.10.2008. godine

1 Šumarski fakultet Univerziteta u Beogradu, Srbija - University of Belgrade, Faculty of Forestry, Serbia
} 
semiglejnim i suvljim glejnim zemljištima) na području jugozapadnog Srema (R. Srbija). Istraživanja na oglednoj površini tokom 2 decenije obuhvataju period nastanka sastojine, strukturnu izgrađenost podmladka u 8. godini i mladika u 19. godini. Sastojina je nastala kombinovanom obnovom u sistemu oplodne seče, uz prethodnu primenu herbicida (Gligosat sa 480 g. $\cdot \mathrm{L}^{-1}$ ) sa ciljem uništavanja izdanački regenerisanih vrsta iz sprata žbunja. U osmoj godini na oglednoj površini drvenaste vrste su bile zastupljene sa 89500 $\mathrm{kom} \cdot \mathrm{ha}^{-1}$, a lužnjak je bio zastupljen sa $42000 \mathrm{kom} \cdot \mathrm{ha}-1$. U ukupnoj strukturi podmlatka lužnjak je bio zastupljen sa $46,9 \%$, poljski jasen sa $0,8 \%$, druge vrste drveća-edifikatora sa $14,5 \%$, a $37,7 \%$ činile su vrste žbunja. U mladiku, u starosti devetnaest godina, evidentirano je devet vrsta drveća, sa ukupno 12341 stabala po ha $^{-1}$ sa debljinom preko 1 $\mathrm{cm}$, a učešće lužnjaka je $68,3 \%\left(8430 \mathrm{kom} \cdot \mathrm{ha}^{-1}\right)$. U periodu od 8 . do 19 . godine mortalitet lužnjaka se procenjuje na $80 \%$.

Ključne reči: Quercus robur L., obnavljanje, trajni ogledi, struktura, podmladak, mladik.

\section{UVOD - Introduction}

U cilju postizanja trajne efikasnosti u ostvarivanju proizvodnih i brojnih drugih funkcija u gazdovanju lužnjakovim šumama najvažniji zadatak je formiranje i održavanje optimalne izgrađenosti sastojina u svim razvojnim fazama. U tom kontekstu, dobro formirane mlade sastojine predstavljaju osnovni preduslov za optimalnu i kvalitetnu produkciju u budućnosti.

Radovi na definisanju savremenih sistema obnove lužnjakovih šuma na području Srema započeti su posle njihovog tipološkog diferenciranja krajem devedesetih godina prošlog veka. $\mathrm{Na}$ osnovu kompleksnih ekoloških i razvojno-proizvodnih istraživanja na prostoru od oko 40.000 ha diferencirano je 12 grupa ekoloških jedinica i 36 tipova šuma (JovIĆ, ET AL. 1989/1990; IVANIŠEVIĆ I KNEŽEVIĆ, 2008). Različiti ekološki uslovi u izdvojenim tipovima šuma ukazali su na potrebu definisanja i diferenciranih prilaza prilikom obnavljanja sastojina. Aktuelno narušavanje biološke stabilnosti u vlažnijim tipovima lužnjakovih šuma, usled hidrotehničkih i melioracijskih radova, uslovilo je prioritetno definisanje sistema obnove, jer su se u njima manifestovale i najizraženije posledice sušenja i recentne sukcesije na širem području savskog regiona (RAUš, 1990, JovIĆ, ET AL. 1994; PRPIĆ, 1996; TOMIĆ, 2002). Na području Srema najviše su zastupljene šume lužnjaka i poljskog jasena (Fraxino angustifoliae-Quercetum roboris Jovanović et TOMı́́, 1979) i šume lužnjaka i poljskog jasena i graba (Carpino-Fraxino-Quercetum roboris Miš. et Broz, 1962), koje su sindinamski usko povezane. Te šume zastupljene su na površini od 22181 ha ili 58,0\% obrasle površine (IVANIŠEVIĆ I KNEŽEVIĆ, 2008). Postupak i specifičnosti obnavljanja šuma lužnjaka i poljskog jasena sa klenom i žešljom na području Srema, mogu se sagledati na osnovu već provedenih istraživanja (BOBINAC, 1999; 2007).

U ovom radu se analiziraju efekti obnavljanja i razvoja sastojine lužnjaka na jednoj trajnoj oglednoj površini tokom 20 godina. Imajući u vidu da istraživanja na oglednoj površini predstavljaju retrospektivu dugu dve decenije, dobijeni rezultati 
omogućavaju zaključke o primenjenom postupku obnavljanja sastojine i određena usmerenja za dalju negu.

\section{MATERIJAL I METODE - Material and Methods}

Efekti obnavljanja lužnjaka analizirani su na jednoj trajnoj oglednoj površini $(\mathrm{P}=0,20 h a)$, koja je formirana na staništu šume lužnjaka i poljskog jasena (Fraxino angustifoliae-Quercetum roboris Jov. et Tom. 1979, subass. aceretosum.-na vlažnijim semiglejnim i suvljim glejnim zemljištima) na području jugozapadnog Srema (R. Srbija). Subasocijacija aceretosum predstavlja terminalnu fazu u razvoju lužnjakovo-jasenove šume, koja je sindinamski i prostorno povezana sa sledećim stadijem - šumom lužnjaka, poljskog jasena i graba sa retkoklasom oštricom (Carpino-Fraxino-Quercetum roboris caricetosum remotae) na livadskim do lesiviranim livadskim crnicama u neplavnom području. Ogledna površina je formirana 1986. godine u sastojini staroj 140 godina i na terenu je locirana na samoj granici te dve šume, na području kojim gazduje ŠG „Sremska Mitrovica“" (GJ Varadin-Županja, odeljenje 51 a).

Tokom 1986. godine na oglednoj površini uklonjen je sprat žbunja, a u leto 1989. god. uništena je izdanačka regeneracija sa herbicidom Cidokor (Gligosat sa $480 \mathrm{~g} \cdot \mathrm{L}^{-1}$ ) u dozi 10 $l \cdot h a^{-1} \mathrm{u}$ folijarnom tretmanu (BOBINAC ET AL., 1991). Površina je prirodno naplođavana $\mathrm{u}$ godinama malog do srednjeg uroda lužnjaka u 1989. i 1990. godini, a 1990. god. izvršeno je i dopunsko podsejavanja žira (setva pod motiku u količini $300 \mathrm{~kg}^{\circ} \mathrm{ha} \mathrm{C}^{-1}$ ), u okviru prirodno ne naplođenih delova na oglednoj površini (BOBINAC, 1990).

U zatečenoj strukturi stare sastojine (posle sprovedenih sanitarnih seča usled devitalizacije i sušenja pretežno poljskog jasena) evidentirano je 110 stabala lužnjaka po $h a$, sa srednjim prečnikom $\mathrm{d}_{g}=55 \mathrm{~cm}$ i zapreminom $\mathrm{V}=353,7 \mathrm{~m}^{3} \cdot h a^{-1}$. U godini naplodnje sa žirom izvršen je oplodni sek i uklonjeno je 50\% stabala. Ponik lužnjaka formirao se u uslovima progaljenog sklopa. Završni sek na podmladnoj površini izvršen je nakon 4 godine od hemijskog tretmana. U periodu od 1991 do 2006. god. u pet navrata je vršeno osvetljavanje podmlatka u klasičnom postupku na površini pripadajućeg odseka, a 2006. god. sprovedena je mera čišćenja mladika, kojom su, pretežno uklonjene nekvalitetne i prekobrojne jedinke graba, poljskog jasena, bresta $\mathrm{i}$ klena iz dominantne i uzgredne etaže.

Efekti podmlađivanja zastupljenih drvenastih vrsta evidentirani su u 8. godini posle totalnog folijarnog tretmana na 20 površina, veličine $2 \mathrm{~m}^{2}$, koje su ravnomerno raspoređene na oglednoj površini. Na svakoj probnoj površini evidentiran je podmadak po vrstama i visinskim klasama sa rasponom od $0,5 \mathrm{~m}$. Premereni uzorak iznosio je $40 \mathrm{~m}^{2}$, odnosno 2,0\% od ukupne površine ogleda (BoBINAC, 1999). U 19. godini na oglednoj površini je izvršen premer prečnika na prsnoj visini svim stablima vrsta drveća, debljine preko $1 \mathrm{~cm}$. Prilikom premera stabla su razvrstana po biološkom položaju na osnovu biološko-gospodarske klasifikacije DEKANIĆA (1964): Adominantna, B-nuzgredna i C-podstojna. Vrste žbunja (podstojna etaža) nisu obuhvaćene premerom. Premer visina lužnjaka izvršen je na po 5 stabala u svakom debljinskom stepenu od $1 \mathrm{~cm}$ i konstruisana je visinska kriva, na osnovu koje je definisana visina srednjeg stabla po preseku. 


\section{REZULTATI - The results}

Visinske klase i prosečna brojnost podmlatka na oglednoj površini u starosti do 8 godina, prikazana je u tabeli 1 . Na podmladnoj površini bilo je prosečno $8,95 \mathrm{kom} \cdot \mathrm{m}^{-2}$ podmlatka drvenastih vrsta. U ukupnoj strukturi podmlatka lužnjak je bio zastupljen sa $46,9 \%$, druge vrste drveća sa $14,5 \%$, a vrste žbunja sa $37,7 \%$. Pored lužnjaka, najzastupljenija vrsta drveća je grab (6,15\%), što je rezultat pridolaska iz neposrednog okruženja podmladne površine (Šuma lužnjaka, graba i poljskog jasena - CarpinoFraxino-Quercetum roboris caricetosum remotae). Veliko učešće vrsta iz sprata žbunja (37,7\%), među kojima su dominirale vrste Rubus sp., Rosa sp. i Crataegus sp., ukazuje da se u strukturi podmlatka odvijala intenzivna interspecijska kompeticija. Podmlađene vrste bile su zastupljene u visinskim klasama u rasponu od 0,5 $m$ do 2,5 $m$. Od prosečne brojnosti lužnjaka u visinskoj klasi do $0,5 \mathrm{~m}$ bilo je zastupljeno $32,7 \%$, a u visinskoj klasi do $1,0 m 62,5 \%$. U visinskoj klasi preko $1 \mathrm{~m}$ bilo je zastupljeno $37,5 \%$ prosečne brojnosti lužnjaka, a $61,6 \%$ prosečne brojnosti drugih vrsta, što je uslovljavalo intraspecijsku kompeticiju i primenu mera nege u narednom periodu.

Tabala 1. Prosečna brojnost podmlatka po $\mathrm{m}^{2}$ u starosti do 8. godina $\left(\mathrm{kom} \cdot \mathrm{m}^{-2}\right)$. Izvor Bobinac (1999) Table 1. Average number of seedlings per $\mathrm{m}^{2}$ at the age of 8 years (trees $\bullet \mathrm{m}^{-2}$ ). Source Bobinac (1999)

\begin{tabular}{|c|c|c|c|c|c|c|c|c|c|c|c|c|}
\hline \multirow[t]{3}{*}{ Vrsta } & \multicolumn{12}{|c|}{ Visinska klasa podmlatka $(\mathrm{m})$} \\
\hline & \multicolumn{2}{|c|}{ do 0,5} & \multicolumn{2}{|c|}{$0,5-1,0$} & \multicolumn{2}{|c|}{$1,0-1,5$} & \multicolumn{2}{|c|}{$1,5-2,0$} & \multicolumn{2}{|c|}{$2,0-2.5$} & \multicolumn{2}{|c|}{ Ukupno } \\
\hline & $\mathrm{N}$ & $\%$ & $\mathrm{~N}$ & $\%$ & $\mathrm{~N}$ & $\%$ & $\mathrm{~N}$ & $\%$ & $\mathrm{~N}$ & $\%$ & $\mathrm{~N}$ & $\%$ \\
\hline Q. robur $\mathrm{L}$. & 1,38 & 32,7 & 1,25 & 29,8 & 0,88 & 20,8 & 0,55 & 13,1 & 0,15 & 3,57 & 4,20 & 100 \\
\hline$\%$ & \multicolumn{2}{|c|}{63,2} & \multicolumn{2}{|c|}{54,9} & \multicolumn{2}{|c|}{43,7} & \multicolumn{2}{|c|}{40,0} & \multicolumn{2}{|c|}{13,3} & \multicolumn{2}{|c|}{46,9} \\
\hline F. angustifolia Vahl & & & & & 0.03 & 33.3 & 0.03 & 33.3 & 0.03 & 33.3 & 0.09 & 100 \\
\hline$\%$ & & & & & \multicolumn{2}{|c|}{1.3} & \multicolumn{2}{|c|}{1.8} & \multicolumn{2}{|c|}{2.2} & \multicolumn{2}{|c|}{0.8} \\
\hline C. betulus L. & 0.08 & 13.6 & 0.18 & 31.8 & 0.03 & 4.50 & 0.20 & 36.4 & 0.08 & 13.6 & 0.53 & 100 \\
\hline$\%$ & \multicolumn{2}{|c|}{3.4} & \multicolumn{2}{|c|}{7.7} & \multicolumn{2}{|c|}{1.3} & \multicolumn{2}{|c|}{14.5} & \multicolumn{2}{|c|}{6.7} & \multicolumn{2}{|c|}{6.2} \\
\hline A. campestre L. & 0.03 & 8.3 & 0.10 & 33.3 & 0.08 & 25.0 & 0.08 & 25.0 & 0.03 & 8.3 & 0.30 & 100 \\
\hline$\%$ & \multicolumn{2}{|c|}{1.2} & \multicolumn{2}{|c|}{4.4} & \multicolumn{2}{|c|}{3.7} & \multicolumn{2}{|c|}{5.4} & \multicolumn{2}{|c|}{2.2} & \multicolumn{2}{|c|}{3.4} \\
\hline A. tataricum L. & & & & & & & & & 0.03 & 100 & 0.03 & 100 \\
\hline$\%$ & & & & & & & & & \multicolumn{2}{|c|}{2.2} & & 3 \\
\hline U campestris $\mathrm{L}$. & & & & & & & 0.05 & 100 & & & 0.05 & 100 \\
\hline$\%$ & & & & & & & 3 & & & & & 6 \\
\hline P. alba L. & & & & & & & 0.03 & 100 & & & 0.03 & 100 \\
\hline$\%$ & & & & & & & & & & & & 3 \\
\hline S. alba L. & & & & & 0.03 & 7.1 & 0.10 & 28.6 & 0.23 & 64.3 & 0.35 & 100 \\
\hline$\%$ & & & & & 1 & & 7 & & & & & 9 \\
\hline Vrste žbunja & 0.70 & 20.7 & 0.75 & 22.2 & 0.98 & 28.9 & 0.35 & 10.4 & 0.60 & 17.8 & 3.38 & 100 \\
\hline$\%$ & 3 & & 33 & & 48 & & 25 & 4 & & & & .7 \\
\hline Ukupno & 2.18 & 24.3 & 2.28 & 25.4 & 2.00 & 22.3 & 1.38 & 15.4 & 1.13 & 12.6 & 8.95 & 100 \\
\hline$\%$ & & & 1( & & 1 & & & & & & & 0 \\
\hline
\end{tabular}

Broj stabala zastupljenih vrsta drveća po ha po biološkim etažama u starosti do 19 godina (stariji mladik) prikazan je u tabeli 2. Od devet zastupljenih vrsta drveća, 
sa ukupno $12341 \mathrm{kom} \cdot \mathrm{ha}^{-1}$ sa debljinom preko $1 \mathrm{~cm}$ na prsnoj visini, najveće učešće ima lužnjak $8430 \mathrm{kom} \bullet \mathrm{ha}^{-1}(68,3 \%)$. Druge vrste drveća zastupljene su sa 3911 $\mathrm{kom} \cdot \mathrm{ha}^{-1}(31,7 \%)$. Pored lužnjaka u strukturi mladika najzastupljeniji je grab i poljski jasen. Od ukupnog broja stabala najveći broj je zastupljen u podstojnoj etaži, 7700 $\mathrm{kom} \cdot \mathrm{ha}^{-1}(62,4 \%)$. U dominantnoj etaži je zastupljeno $3346 \mathrm{kom}^{\circ} \mathrm{ha}^{-1}(27,1 \%)$, a u međustojećoj $1295 \mathrm{kom} \bullet \mathrm{ha}^{-1}(10,5 \%)$. U svim etažama dominira lužnjak, sa učešćem od $92,6 \%$ u dominantnoj etaži, do $56,0 \%$ u podstojnoj etaži. U dominantnoj etaži lužnjak je zastupljen sa $3100 \mathrm{kom} \bullet \mathrm{ha}^{-1}(92,6 \%)$, a ostale vrste zastupljene su sa 246 $\mathrm{kom} \bullet \mathrm{ha}^{-1}(7,4 \%)$. U podstojnoj etaži lužnjak je zastupljen sa $4315 \mathrm{kom} \bullet \mathrm{ha}^{-1}(56,0 \%)$, a ostale vrte drveća zastupljene su sa $3385 \mathrm{kom}_{\bullet} \mathrm{ha}^{-1}(44,0 \%)$. Ostale vrste drveća pretežno su zastupljene u međustojećoj i podstojnoj etaži.

Tabela 2. Struktura mladika u starosti 19 godina $\left(\mathrm{kom} \bullet \mathrm{ha}^{-1}\right)$

Table 2. Sapling structure at the age of 19 years (trees $\bullet \mathrm{ha}^{-1}$ )

\begin{tabular}{|c|c|c|c|c|c|c|c|c|}
\hline \multirow[t]{3}{*}{ Vrsta } & \multicolumn{8}{|c|}{ Biolološka etaža - Biological position } \\
\hline & \multicolumn{2}{|c|}{ A } & \multicolumn{2}{|c|}{$\mathrm{B}$} & \multicolumn{2}{|c|}{$\mathrm{C}$} & \multicolumn{2}{|c|}{ Ukupno } \\
\hline & $\mathrm{N}$ & $\%$ & $\mathrm{~N}$ & $\%$ & $\mathrm{~N}$ & $\%$ & $\mathrm{~N}$ & $\%$ \\
\hline Q. robur $\mathrm{L}$. & 3100 & 36.8 & 1015 & 12.0 & 4315 & 51.2 & 8430 & 100.0 \\
\hline$\%$ & \multicolumn{2}{|c|}{92.6} & \multicolumn{2}{|c|}{78.4} & \multicolumn{2}{|c|}{56.0} & \multicolumn{2}{|c|}{68.3} \\
\hline F. angustifolia & 90 & 12.3 & 70 & 9.6 & 570 & 78.1 & 730 & 100.0 \\
\hline$\%$ & \multicolumn{2}{|c|}{2.7} & \multicolumn{2}{|c|}{5.4} & \multicolumn{2}{|c|}{7.4} & \multicolumn{2}{|c|}{5.9} \\
\hline C. betulus L. & 25 & 1.7 & 60 & 4.1 & 1375 & 94.2 & 1460 & 100.0 \\
\hline$\%$ & \multicolumn{2}{|c|}{0.7} & \multicolumn{2}{|c|}{4.6} & \multicolumn{2}{|c|}{17.9} & \multicolumn{2}{|c|}{11.8} \\
\hline A. campestre L. & 20 & 3.1 & 25 & 3.9 & 595 & 93.0 & 640 & 100.0 \\
\hline$\%$ & \multicolumn{2}{|c|}{0.6} & \multicolumn{2}{|c|}{1.9} & \multicolumn{2}{|c|}{7.7} & \multicolumn{2}{|c|}{5.2} \\
\hline A. tataricum $\mathrm{L}$. & 10 & 5.0 & 10 & 5.0 & 180 & 90.0 & 200 & 100.0 \\
\hline$\%$ & \multicolumn{2}{|c|}{0.3} & \multicolumn{2}{|c|}{0.8} & \multicolumn{2}{|c|}{2.3} & \multicolumn{2}{|c|}{1.6} \\
\hline U campestris L. & 96 & 12.3 & 100 & 12.8 & 585 & 74.9 & 781 & 100.0 \\
\hline$\%$ & \multicolumn{2}{|c|}{2.9} & \multicolumn{2}{|c|}{7.7} & \multicolumn{2}{|c|}{7.6} & \multicolumn{2}{|c|}{6.3} \\
\hline S. alba L. & & & 5 & 5.9 & 80 & 94.1 & 85 & 100.0 \\
\hline$\%$ & & & \multicolumn{2}{|c|}{0.4} & \multicolumn{2}{|c|}{1.0} & \multicolumn{2}{|c|}{0.7} \\
\hline P. communis L. & 5 & 50.0 & 5 & 50.0 & & & 10 & 100.0 \\
\hline$\%$ & & & & & & & & \\
\hline M. silvestris $\mathrm{S}$. & & & 5 & 100.0 & & & 5 & 100.0 \\
\hline$\%$ & & & & & & & & \\
\hline Ukupno & 3346 & 27.1 & 1295 & 10.5 & 7700 & 62.4 & 12341 & 100.0 \\
\hline$\%$ & & & & & & & & \\
\hline
\end{tabular}

Osnovni elementi rasta lužnjaka u mladiku prikazani su u tabeli 3. Ukupnu strukturu mladika po ha karakteriše temeljnica od $\mathrm{G}=16,91 \mathrm{~m}^{2} \cdot h \mathrm{a}^{-1}$, srednji prečnik po temeljnici $d_{g}=5,0 \mathrm{~cm}$ i srednja visina. $h_{g}=7,7 \mathrm{~m}$. U ukupnom broju stabala lužnjaka u dominantnoj etaži zastupljeno je 36,8\% stabala i 71,6\% temeljnice, a u podstojnoj etaži zastupljeno je $51,2 \%$ stabala i $18,1 \%$ temeljnice. Srednji prečnik stabala po temeljnici u dominantnoj etaži iznosi 7,0 cm, što je 1,49 puta veća veličina od srednjeg prečnika stabala iz nuzgredne etaže i 2,33 puta veća veličina od srednjeg prečnika stabala iz podstojne etaže. Srednja visina stabala u dominantnoj etaži iznosi $8,7 \mathrm{~m}$, što je 1,16 puta veća veličina od srednje visine stabala iz nuzgredne etaže i 1,38 puta veća 
veličina od srednje visine stabala iz podstojne etaže. Stabla iz dominantne etaže karakteriše stepen vitkosti $h / d=124$, a stabla iz podstojne etaže $h / d=210$.

Tabela 3. Elementi rasta lužnjaka u mladiku u 19. godini (2008.god.) po biološkim etažama

Table 3. Growth elements of common oak saplings at the age of 19 years (in 2008) by crown classes

\begin{tabular}{|c|c|c|c|c|c|c|c|c|c|c|c|c|c|c|c|}
\hline \multicolumn{12}{|c|}{ Biološka etaža- Biological position } & \multirow{2}{*}{\multicolumn{4}{|c|}{ Ukupno }} \\
\hline \multicolumn{4}{|c|}{ A } & \multicolumn{4}{|c|}{$\mathrm{B}$} & \multicolumn{4}{|c|}{$\mathrm{C}$} & & & & \\
\hline $\mathrm{N}$ & $\%$ & $\mathrm{G}$ & $\%$ & $\mathrm{~N}$ & $\%$ & $\mathrm{G}$ & $\%$ & $\mathrm{~N}$ & $\%$ & $\mathrm{G}$ & $\%$ & $\mathrm{~N}$ & $\%$ & $\mathrm{G}$ & $\%$ \\
\hline 3100 & 36.8 & 12.11 & 71.6 & 1015 & 12.0 & 1.74 & 10.3 & 4315 & 51.2 & 3.06 & 18.1 & 8430 & 100 & 16.91 & 100 \\
\hline \multicolumn{4}{|c|}{$d_{g}=7,0 \mathrm{~cm}$} & \multicolumn{4}{|c|}{$d_{g}=4,7 \mathrm{~cm}$} & \multicolumn{4}{|c|}{$d_{g}=3.0 \mathrm{~cm}$} & \multicolumn{4}{|c|}{$d_{g}=5.0 \mathrm{~cm}$} \\
\hline \multicolumn{4}{|c|}{$h_{g}=8,7 \mathrm{~m}$} & \multirow{2}{*}{\multicolumn{4}{|c|}{$\begin{array}{c}h_{g}=7,5 \mathrm{~m} \\
\mathrm{~h} / \mathrm{d}=160\end{array}$}} & \multicolumn{4}{|c|}{$h_{g}=6,3 \mathrm{~m}$} & \multirow{2}{*}{\multicolumn{4}{|c|}{$\frac{h_{g}=7,7 \mathrm{~m}}{\mathrm{~h} / d=154}$}} \\
\hline \multicolumn{4}{|c|}{$h / d=124$} & & & & & \multicolumn{4}{|c|}{$h / d=210$} & & & & \\
\hline
\end{tabular}

\section{DISKUSIJA - Discussion}

U izmenjenim i vrlo dinamičnim uslovima $u$ terminalnoj zajednici šume lužnjaka i poljskog jasena (Fraxino angustifoliae-Quercetum roboris Jov. et Tom., 1979, subass. aceretosum) na području jugozapadnog Srema, prirodna obnova sastojina je otežana i mora se izvoditi uz pomoćne mere. Pomoćne mere u sastojinama za obnovu primarno se sprovode u cilju uklanjanja sprata žbunja i uništavanja izdanačke regeneracije sasečenih vrsta. Kada je sprat žbunja u progresiji, racinalizovani tehnološki postupak pripreme sastojina za obnovu na području Srema podrazumeva njegovo uklanjanje pomoću uređaja Willibald i redukciju izdanačke regeneracije $\mathrm{u}$ početnim fazama razvoja translokacionim herbicidima. Rezultati istraživanja na definisanju takvog pristupa (BOBINAC I JEZDIĆ, 1991; BOBINAC ET AL., 1991; BOBINAC I ŠIMUNOVAČKI, 2000) omogućili su praktičnu razradu postupka koji danas preovlađuje u procesu obanavljanja ,zakorovljenih“ i degradiranih lužnjakovih sastojina na području Srema (BOBINAC, 1999; 2007; 2008). Imajući u vidu činjenicu da se pri takvom postupku represivno utiče na šumski ekosistem, prikazani podaci na analiziranoj trajnoj oglednoj površini omogućavaju analizu efekata obnavljanja lužnjaka i drugih vrsta. Takođe, imajući u vidu strukturnu izgrađenost mladika, prikazani podaci omogućavaju usmerenja za projekciju mera nege u budućnosti.

Značajno prisustvo sporednih drvenastih $i$ žbunastih vrsta $u$ strukturi podmlatka, u starosti do 8 godina, ukazuje da se u nepovoljnoj strukturnoj i cenološkoj izgrađenosti podstojnog sprata u sastojinama za obnovu, jednokratnom primenom herbicida (Gligosat sa $480 \mathrm{~g} \cdot \mathrm{L}^{-1}$ ) ne uništava biološki potencijal za regeneraciju zastupljenih vrsta. Takođe, ne sprečava se semenska obnova vrsta lakšeg semena na sečinama malih površina iz neposrednog okruženja. U strukturi podmlatka zastupljenost vrsta žbunja od prosečno $3,38 \mathrm{kom} \cdot \mathrm{m}^{-2}$, odnosno ukupno $4,75 \mathrm{kom} \cdot \mathrm{m}^{-2}$ drugih drvenastih vrsta, u odnosu na prosečan broj lužnjaka od $4,20 \mathrm{kom} \cdot \mathrm{m}^{-2}$ ukazuje da se u narednom periodu mogla očekivati značajna interspecijska i intraspecijska kompeticija u podmlatku. Primenom mera nege (osvetljavanje podmlatka i čišćenje 
mladika na principu negativne selekcije) usmereno su poboljšavani uslovi za razvoj lužnjaka i on na oglednoj površini dominira u strukturi mladika.

Za uspešnu obnovu lužnjakovo-grabovih sastojina MATIĆ (1994) navodi da je u starosti podmlatka 3-10 godina potrebno imati $40.000-50.000 \mathrm{kom} \bullet \mathrm{ha}^{-1}$, glavnih vrsta, sa učešćem lužnjaka $80 \%$. Zastupljenosti lužnjaka u ukupnoj strukturi podmladika na istraživanoj oglednoj površini u Sremu od $42000 \mathrm{kom} \bullet \mathrm{ha}^{-1}$ ukazuje da je u primenjenom postupku obnavljanja i nege formirana mlada sastojina sa dovoljnim brojem stabala lužnjaka po hektaru.

$\mathrm{Na}$ osnovu relativnog učešća lužnjaka u ukupnom broju stabala u 8. i 19. godini, učešće lužnjaka je značajno veće u 19. godini, što je rezultat mera nege. Međutim, u formiranoj strukturnoj izgrađenosti podmlatka i sprovedenom postupku nege, u periodu od 8. do 19. godine mortalitet lužnjaka je aproksimativno iznosio oko $80 \%$. Na osnovu proučavanja obnove šuma hrasta lužnjaka vlažnog tipa u klasičnom postupku, KREJČI I DUBRAVAC (2004) konstatuju preživljavanje podmlatka u periodu od 3. do 10 . godine u iznosu od $22 \%$, a glavne razloge za mali procenat preživljavanja podmlatka lužnjaka nalaze u interspecijskoj konkurenciji na podmladnim površinama. Za dalju negu mladika, na principu pozitivne selekcije, opredeljujuće je učešće lužnjaka u dominantnoj etaži. Zastupljenost lužnjaka u dominantnoj etaži sa 3100 $\mathrm{kom} \bullet \mathrm{ha}^{-1}(92,6 \%)$, sa srednjim prečnikom od 7,0 $\mathrm{cm}$ i srednjom visinom od $8,7 \mathrm{~m}$, ukazuje da će u narednom periodu u dominantnoj etaži preovladava izrazita intraspecijska kompeticija (lužnjak-lužnjak), pa je tom procesu potrebno prilagoditi i mere nege u budućnosti (posebno iz razloga što je u toj etaži skoncentrisan potencijal stabala za prioritetnu negu). $\mathrm{Na}$ osnovu podataka o prirodnim diferenciranju i mortalitetu stabala u mladim lužnjakovim sastojinama (DEKANIĆ, 1964; MATIĆ, 1989; BOBINAC I FERLIN, 1996; BOBINAC ET AL, 1997; FERLIN I BOBINAC, 1999) sa sigurnošću se može tvrditi da će se iz podstojne etaže vrlo brzo izlučiti $4315 \mathrm{kom} \bullet \mathrm{ha}^{-1}$ ili $51,2 \%$ od ukupnog broja stabala lužnjaka, ali i sa velikim stepenom sigurnosti, pretpostaviti, da će pri daljem spontanom razvoju i iz nuzgredne etaže izlučiti značajan broj od 1015 $k o m \cdot h a^{-1}$ u podstojnu etažu i kasnije predstavljati prirodni mortalitet. Intenzivniji procesi diferenciranja stabala po debljini u odnosu na diferenciranje stabala po visini, u narednom periodu usloviće povećanje stepena vitkosti stabala iz nuzgredne etaže, što će povećati njihovu nestabilnost $(h / d=160)$. Stoga, primarnu bazu stabala za dalji (spontan) razvoj sastojine u 19. godini predstavljaju samo stabla lužnjaka iz dominantne etaže $\left(3100 \mathrm{kom} \bullet \mathrm{ha}^{-1}\right)$. Za potvrdu takvog stava mogu poslužiti noviji modeli na osnovu kojih se definiše normalan broj stabala hrasta lužnjaka u šumama vlažnog tipa (BEZAK ET AL., 1993) i prognozni modeli na osnovu istraživanja (DuBRAVAC, 2003; ČAVlović ET AL., 2006), u kojima se za sastojine stare 20 godina definiše manji broj stabala od utvrđenog u dominantnoj etaži na istraživanoj oglednoj površini.

Navedena razmatranja ukazuju na zadovoljavajuću obnovu lužnjaka i drugih vrsta, ali i upućuju na činjenicu da je mortalitet lužnjaka u periodu od 8. do 19. godine aproksimativno iznosio oko $80 \%$, pri sprovedenom postupku. Takođe, kada se ima u vidu da broj stabala lužnjaka u dominantnoj etaži predstavlja aproksimativno samo oko $7 \%$ u odnosu na broj stabala lužnjaka u podmlatku u 8. godini, ta činjenica ukazuje na potrebu kreiranja alternativnih uzgojnih strategija u procesu formiranja 
lužnjakovih sastojina u pojedinim tipovima šuma, jer se u sprovedenom postupku lužnjak može definisati kao kompetitor, koji se u značajnoj meri izlučuje iz sastojine do početka primene mera nege na principu pozitivne selekcije.

\section{ZAKLJUČCI - Conclusions}

Posle 8. i 19. godine od primene herbicida (Gligosat sa $480 \mathrm{~g} \cdot \mathrm{L}^{-1}$ ) u dozi 10 $l \cdot h a^{-1}$, sa ciljem uništavanja izdanački regenerisanih vrsta iz sprata žbunja i stvaranja povoljnih uslova za podmlađivanje lužnjaka, mogu se doneti sledeći zaključci:

- Prosečan broj podmladka drvenastih vrsta na podmladnoj površini u 8. godini bio je $8,95 \mathrm{kom} \bullet \mathrm{m}^{-2}$, sa učešćem lužnjaka $46,9 \%\left(4,20 \mathrm{kom} \bullet \mathrm{m}^{-2}\right)$.

- Od prosečne brojnosti lužnjaka u visinskoj klasi do $0,5 \mathrm{~m}$ bilo je zastupljeno $32,7 \%$, a u visinskoj klasi do $1,0 \mathrm{~m} 62,5 \%$. U visinskoj klasi preko $1 \mathrm{~m}$ bilo je zastupljeno $37,5 \%$ prosečne brojnosti lužnjaka, a $61,6 \%$ prosečne brojnosti drugih vrsta, što je uslovljavalo intraspecijsku kompeticiju i primenu mera nege u narednom periodu.

- U mladiku, starosti 19. godina, zastupljeno je devet vrsta drveća, sa ukupno $12341 \mathrm{kom} \bullet \mathrm{ha}^{-1}$. Najveće učešće ima lužnjak sa $8430 \mathrm{kom} \bullet \mathrm{ha}^{-1}(68,3 \%)$.

- Od ukupnog broja stabala u mladiku najveći broj je zastupljen u podstojnoj etaži, $7700 \mathrm{kom} \bullet \mathrm{ha}^{-1}(62,4 \%)$. U dominantnoj etaži lužnjak je zastupljen sa $3100 \mathrm{kom} \bullet \mathrm{ha}^{-1}(92,6 \%)$, a u podstojnoj etaži sa $4315 \mathrm{kom} \bullet \mathrm{ha}^{-1}(56,0 \%)$.

- Veliki stepen vitkosti stabala iz podstojne $(\mathrm{h} / \mathrm{d}=210)$ i međustojeće $(\mathrm{h} / \mathrm{d}=160)$ etaže ukazuje na njihovu statičku nestabilnost i u daljem procesu biološkog diferenciranja ta stabla mogu imati samo sekundarnu ulogu u strukturi sastojine. Realnu bazu u 19. godini za dalji (spontan) razvoj sastojine predstavljaju samo stabla lužnjaka iz dominantne etaže $\left(3100 \mathrm{kom} \mathrm{ha}^{-1}\right)$.

\section{LITERATURA - References}

BeZAK, K., KREJČI, V., KRZNAR, A. (1993): Prirasno-prihodne tablice hrasta lužnjaka u šumama vlažnog tipa. Radovi, Vol. 28, br. 1-2, 55-67, Jastrebarsko.

BoBINAC, M. (1990): Prilog poznavanju nekih faktora prirodne obnove lužnjaka u Sremu, Šumarstvo 3-4, 27-32, Beograd.

BoBINAC, M. (1999): Istraživanja prirodne obnove lužnjaka (Quercus robur L.) i izbor metoda obnavljanja u zavisnosti od stanišnih i sastojinskih uslova. Doktorska disertacija, rukopis, str. 262, Beograd.

BOBINAC, M. (2007): Oplodna sječa u šumi lužnjaka i poljskog jasena u Srijemu i njene specifičnosti. Pregledni rad, Radovi, Vol. 42, br. 1, 33-46, Jastrebarsko.

BoBINAC, M. (2008): Savremeni pristup obnovi šuma tvrdih lišćara na području ravnog Srema. Monografija „250 godina šumarstva Ravnog Srema“. Javno preduzeće „Vojvodinašume“-Šumsko gazdinstvo Sremska Mitrovica, Ur. Z. Tomović, 127-136, Petrovaradin. 
BOBINAC, M., FERLIN, F. (1996): Characteristics of biological differentiation of trees in a young untended pedunculate oak stands. ICWSF, Proceedings, 334-340, Sopron.

BoBINAC, M., JEZDIĆ, D. (1991): Šumski mulčer Willibald UFM-180 u agregatu sa traktorom Rakovica-135, mogućnosti i primena u uzgojnim radovima, Šumarstvo 5, 61-69, Beograd.

BobINAC, M., ŠIMUNOVAČKI, Đ. (2000): Mogućnosti primene totalnog folijarnog tretmana u procesu pripreme sastojina lužnjaka za semenu obnovu. Šumarstvo 6, 1-10, Beograd.

BobinaC, M., KARADŽIĆ, D., CVJetIĆANIN, R. (1991): Primena herbicida kod pripreme sastojina lužnjaka za pri-rodnu obnovu, Glasnik Šumarskog fakulteta 73, 220-229, Beograd.

Bobinac, M., P. Grbić, G. Janjatović, Abjanović, Z. (1997): Prorede u mladim sastojinama lužnjaka i poljskog jasena na području Š.G. "Sremska Mitrovica", Šumarstvo 4-5, 33-43, Beograd.

Čavlović, J., Božlć, M., KRUnoslaV, T. (2006): Mogućnosti uspostave potrajnog gospodarenja šumama hrasta lužnjaka u budućim gospodarskim razdobljima. Glasnik za šumske pokuse, posebno izdanje 5, 419-431, Zagreb.

DEKANIĆ, I. (1964): Metodi intenzivnog proređivanja sastojina visokog uzrasta. Dokumentacija za tehniku i tehnologiju u šumarstvu, br. 46, JŠPC, 1-79, Beograd.

DuBRAVAC, T. (2003): Dinamika razvoja promjera krošanja hrasta lužnjaka i običnog graba ovisno o prsnom promjeru i dobi. Radovi, Vol. 38, br. 1, 35-54, Jastrebarsko.

FERLIN, F. BOBINAC, M. (1999): Natürliche Strukturentwicklung und Umsetzungsvorgänge in jüngeren, ungepflegten Stieleichenbeständen. Allg. Forst-u. J.- Ztg., 170. Jg., 8, 137-142, Frankfurt am Mein.

IVANIŠEVIĆ, P., KNEŽEVIĆ, M. (2008): Tipovi šuma i šumskog zemljišta na području Ravnog Srema. Monografija „250 godina šumarstva Ravnog Srema“. Javno preduzeće „Vojvodinašume“-Šumsko gazdinstvo Sremska Mitrovica, Ur. Z. Tomović, 87-118, Petrovaradin.

Jović, D., Banković, S., Medarević, M., GRBić, P. (1994): Sušenje šuma lužnjaka i poljskog jasena u Sremskom šumskom području, U: Aerozagađenja i šumski ekosistemi, Šumarski fakultet i Centar za multidisciplinarne studije, 179-194, Beograd.

Jović, N., D. Jović, B. Jovanović, Z. Tomı́́ (1989/1990): Tipovi lužnjakovih šuma u Sremu i njihove osnovne karakteristike, Glasnik Šumarskog fakulteta 71-72, 19-41, Beograd.

KREJČl, V., DubravaC, T. (2004): Problemi obnove šuma hrasta lužnjaka (Quercus robur L.) vlažnog tipa tijekom oplodnih siječa. Šumarski list, 3-4, CXXVIII, 119-126, Zagreb.

MATIĆ, S. (1989): Intenzitet prorede i njegov utjecaj na stabilnost, proizvodnost i pomlađivanje sastojina hrasta lužnjaka, Glasnik za šumske pokuse 25, 261-278, Zagreb. 
MATIĆ, S. (1994): Prilog poznavanju broja biljaka i količine sjemena za kvalitetno pomlađivanje i pošumljavanje, Šumarski list 3-4, 71-79, Zagreb.

PRPIĆ, B. (1996): Propadanje šuma hrasta lužnjaka, U: Hrast lužnjak (Querqus robur L.) u Hrvatskoj, monografija, 273-298, Vinkovci - Zagreb.

RAUŠ, Đ. (1990): Sukcesija šumske vegetacije u bazenu Spačva u razdoblju 1970-1989 godine, Šumarski list CXIV, 341-356, Zagreb.

Tomić, Z., Jović, N. (2002): Recentna sukcesija šume lužnjaka i poljskog jasena u neplavnom delu gornjeg Srema. Glasnik Šumarskog fakulteta 85, Univerzitet u Beogradu-Šumarski fakultet, 101-112, Beograd.

\section{SUMMARY - Sažetak}

The effects of common oak stand regeneration and development were analysed in a permanent sample plot during a period of 20 years. The sample plot $(\mathrm{P}=0.20 \mathrm{ha}$ ) was established in 1986 on the site of common oak and narrow-leaved ash forest (Fraxino angustifoliae-Quercetum roboris Jov. et Tom. 1979, subass. aceretosum - on moister semigleys and drier gleys) in the area of southwest Srem (Serbia).

The research includes the period of stand establishment, the structure of the regeneration in the eighth year, and saplings in $19^{\text {th }}$ year of age. The stand was established by the combined regeneration in the system of regeneration felling, with the preliminary application of subsidiary measures. In 1989, a herbicide (Glyphosate $480 \mathrm{~g} \cdot \mathrm{L}^{-1}$ ) was applied in total foliar treatment to destroy the coppice woody species in the shrub layer. Eight years after the herbicide treatment, the average number of woody species on the regeneration area was 8.95 trees $\cdot \mathrm{m}^{-2}$, and common oak 4.20 trees $\cdot \mathrm{m}^{-2}$ or $46.9 \%$. The significant presence of secondary tree and shrub species in the regeneration structure indicates that, in the unfavourable structural and coenological state of the understory in the stand for regeneration, a single herbicide application (Glyphosate $480 \mathrm{~g}^{\bullet} \mathrm{L}^{-1}$ ) did not destroy the biological regeneration potential of some species. Also, it did not prevent the regeneration from seeds of the species with lighter seeds on small-sized felling areas in the direct surroundings.

The regenerated species were represented in height classes from $0.5 \mathrm{~m}$ to $2.5 \mathrm{~m}$. Of the average number of common oaks 4.20 trees $\cdot m^{-2}(100 \%), 32.7 \%$ were in the class below $0.5 \mathrm{~m}$ and $62.5 \%$ in the height class below $1.0 \mathrm{~m}$. 37.5\% of common oak average were in the class above $1 \mathrm{~m}$, and $61,6 \%$ were the other tree species, which conditioned a severe intra-species competition, requiring some tending operations (liberation cutting). The saplings at the age of 19 years consisted of 10 tree species, with 12,341 trees $\cdot h a^{-1}$, with the diameter at breast height above $1 \mathrm{~cm}$. The highest percentage was achieved by common oak 8,430 trees $h a^{-1}(68.3 \%)$. Of the total number of trees, the highest number belonged to the understory 7,700 trees $h a^{-1}$ (62.4\%). In the dominant story, common oak amounted to 3,100 trees $h a^{-1}(92.6 \%)$, and other species - 246 trees $h a^{-1}(7.4 \%)$. In the understory, common oak amounted to 4,315 trees $h a^{-1}(56.0 \%)$, and other tree species amounted to 3,385 trees $h a^{-1}(44.0 \%)$. A high degree of tree taper in the understory $(\mathrm{h} / \mathrm{d}=210)$ and subdominant storey 
$(\mathrm{h} / \mathrm{d}=160)$ points to their static instability and in the further process of biological differentiation, these trees can have only the secondary role in the stand and represent the natural mortality. The real base for further (spontaneous) stand development in the $19^{\text {th }}$ year consists only of common oak trees in the dominant story $\left(3,100\right.$ trees $\left.^{\prime} \cdot \mathrm{ha}^{-1}\right)$.

The above analysis points to the satisfactory regeneration of common oak and other species in the above procedure, but it also points out the fact that common oak mortality at the ages of 8 to 19 years was approximately $80 \%$. Also, when it is taken into account that the number of common oaks in the dominant storey wa approximately only about $7 \%$ compared to the number of common oaks in the regeneration at the age of 8 years, this fact indicates that it is necessary to create some alternative silvicultural strategies in the process of common oak stand establishment in some forest types, because in the above procedure of stand establishment, common oak can be defined as a competitor, which is to a significant extent removed from the stand before the beginning of tending operations, by the principle of positive selection. 